\title{
Hospital Waste Management through Green QFD Implementation
}

\author{
R.Joegijantoro ${ }^{l}$ \\ ${ }^{I}$ Widyagama Husada School of Health, Malang Indonesia \\ *Email:rudyjoegijantoro@widyagamahusada.ac.id
}

\begin{abstract}
Based on case studies conducted in various health institutions, the high production of medical waste is one proof that medical waste management is still problematic. This study examines various problems in the field of medical waste management. This study explores staff perceptions of medical waste management. This study aims to determine the level of knowledge and attitudes as well as the role of health workers on medical waste management. Here we study the quality index and environmental index of two health care centers, one is a private hospital and one is a government hospital and compared these two indices with each other via a questionnaire survey. To produce more environmentally friendly services, customers, and environmental criteria must be considered during the decision-making process, and the Implementation of Green QFD (G-QFD) provides a very useful methodology to meet this goal.
\end{abstract}

Keywords-Waste management, Quality Function Deployment, Green QFD.

Paper type: Research paper

\section{INTRODUCTION}

The main objective of the ecological design is to create sustainable services for society that will not only reduce the impact on the environment, but also take into account customer expectations and the economic realities of those services. From this perspective, the Green-QFD methodology is a useful technique for that, not only from the traditional point of view of cost or customers, but also from an environmental perspective.

Modern hospitals and health care institutions, including research centers, use a wide variety of drugs, including antibiotics, cytotoxics, corrosive chemicals, radioactive substances, which eventually become hospital waste. Access to hospitals has had negative consequences, namely inadequate recycling, unauthorized and illegitimate reuse and increased waste. All technological advances have increased the availability of health-related consumer goods, which are prone to breakage.

According to the Ministry of Health, hospital waste is all waste generated from hospital activities in the form of solid, liquid, paste (gel) or gas which can contain infectious pathogenic microorganisms, toxic chemicals, and some are radioactive. By looking at this description, the waste originating from this hospital can be categorized as B3 waste (hazardous and toxic waste).

Hospital waste itself is a heterogeneous mixture of its properties. All of these types of waste can contain potentially infectious waste. Sometimes, incineration residual waste can be categorized as hazardous waste if a hospital's incinerator does not meet the criteria, or is not operated according to the criteria.

To optimize the environmental health efforts of the hospital from the waste pollution it produces, the hospital must have its own waste management facility stipulated in the Republic of Indonesia's Minister of Health Decree No. 1204 / Menkes / SK / X / 2004 concerning Hospital Environmental Health Requirements :

1. Solid Waste Management Facility - Each hospital must perform waste reduction starting from the source and must manage and supervise the use of hazardous, toxic chemicals and any equipment used in medical waste management starting from collection, transportation, and disposal must go through a certification from authorized party.

2. Liquid Waste Treatment Facilities - Liquid waste must be collected in containers according to the chemical and radiological characteristics, volume, and handling and storage procedures. The hospital must have its own Wastewater Treatment Plant.

Waste from health services such as hospitals can be classified into several main categories, namely general waste, pathological waste (body tissue), radioactive waste, chemical waste, potentially infectious waste, sharp objects, pharmaceutical waste, cytotoxic waste, and container under pressure. Of the many types of clinical waste, one that requires special attention is waste that can cause infectious diseases (infectious waste) or biomedical waste. This waste is usually only $10-15 \%$ of the total volume of waste from health service activities. The specific types of waste are:

- Human anatomical waste: human tissues, organs, body parts, but excluding teeth, hair and face. 
- Animal waste: body tissues, organs, carrion, blood, parts contaminated with blood, etc., but excludes teeth, hair, nails.

- Microbiology laboratory waste: body tissue, animal or microorganism stock, vaccines, or laboratory materials or equipment that came into contact with these materials.

- Waste of blood and human fluids or materials / equipment contaminated with them. Not included in this category are urine and feces.

- Sharps such as needles, scissors, broken glass and so on.

The goal of hospital waste management is how to handle hazardous waste, get rid and destroy it as economically as possible, yet hygienically and not endanger the environment. For general waste, the handling is identical to other domestic wastes. Recycling wherever possible is applied to every opportunity. Uninfected sharp materials must be properly wrapped and will not harm the handling workers and can be disposed of like general waste, while infected sharps are treated as hazardous waste.

In general, the types of hospital waste treatment are:

1. General waste; a kind of domestic waste, packaging materials, non-infectious pet food, waste from washing and other materials that do not harm human health and the environment. This waste treatment does not require special treatment, and can be combined with domestic waste. All food that has left the kitchen in principle is waste if not consumed and food scraps from the infectious disease department need to be autoclaved before being disposed of in the landfill.

2. Pathological waste; consists of tissues, organs, body parts, placenta, animal carcasses, blood and body fluids. This waste treatment is carried out by sterilization, incineration, then followed by landfilling. Incineration is the highly recommended method, the bags used to wrap waste should also be incinerated.

3. Radioactive waste; They can be solid, liquid or gas phases contaminated with radionuclycides, and result from invitro analysis of body tissues and fluids, or in-vivo analysis of organs for tumor tracking or localization, or result from therapeutic procedures. Radioactive materials used in health / medical activities are usually classified as having a low level of radioactivity power, which is below 1 megabecquerel (MBq). Radioactive waste from hospitals can be said to not contain significant hazards if handled properly. Waste treatment can be carried out within the hospital premises itself, and is generally stored to wait for its half-life to expire, to then be disposed of as ordinary nonradioactive waste.

4. Chemical waste; can be solids, liquids or gases for example from diagnostic or research work, cleaning / maintenance or disinfection procedures. For non-hazardous chemical waste, its handling is identical to other wastes that are not categorized as hazardous. The concept of handling hazardous chemical waste is identical to the previous explanation contained in this text on hazardous waste.

5. Waste has the potential to transmit disease (infectious); contains pathogenic microorganisms which can be seen from the concentration and quantity when exposed to humans can cause disease. The categories that include this waste include tissue and stocks from infectious agents from laboratory activities, from operating rooms or from autopsy of patients with infectious diseases, or from isolated patients, or material in contact with patients undergoing haemodialysis (tubes, filters, napkins, gowns, gloves, etc.) or materials that come into contact with an animal that is being inoculated with an infectious disease or is suffering from an infectious disease. This waste treatment requires sterilization first or is handled directly in the incinerator. Autoclave is not required if the waste has been properly accommodated and handled prior to incineration.

6. Sharp objects; in the form of syringes, syringes, scissors, knives, broken glass, nail clippers and so on that can cause people to be stabbed (injured) and infection occurs. These items may be contaminated with blood, body fluids, microbiological or cytotoxic substances. This waste must be packed in packaging that can protect personnel from the danger of being punctured, before being incinerated in an incinerator.

7. Pharmaceutical waste: in the form of pharmaceutical products, drugs and chemicals that have been returned from the isolation patient's room, or have been spilled, expired or contaminated or must be disposed of because they are no longer used. Medicines that are not used and have long expired time are returned to the pharmacy, while those that are not used and are approaching or have expired are handled specifically, for example incinerated or landfilled or returned to suppliers.

8. Containers are under pressure; in the form of cylinders containing gas and aerosols which can explode when incinerated or if they are damaged due to an accident (punctured and so on). Processing by landfilling or recycling.

\section{LITERARURE REVIEW}

In the classic QFD created by Akao (Akao, 1991) it is still not possible to integrate environmental and cost problems into its matrices. Therefore, in 1996 Cristophari (Zhang, 1999) made a Green QFD in which environmental issues were considered. However, according to Zhang (1999) Green QFD is still not efficient because it has not considered costs in its matrices. Starting in 1998, Zhang et al (1998) began to develop QFD so that it could integrate aspects of quality, environment, and cost into its matrices. 
The versions of Green-QFD help select the best alternative services taking into account environmental, customer and cost requirements. Cristofari et al. (1996) combining Quality Function Deployment (QFD) and Green-QFD, Mehta and Wang (2001) used the Eco-Indicator'99 method (Goedkoop and Spriensma, 1999) to measure the environmental impact of products in Green-QFD III. Lastly, Dong et al. (2002) incorporated a fuzzy multi-attribute utility theory to estimate life cycle costs in Green-QFD IV.

QFD process

QFD should be viewed from a very global perspective as a methodology that a company will associate with its clients and will assist the organization in its planning process. The goal of QFD is not to create a matrix but to touch clients and use this knowledge to develop products that satisfy customers and use different matrices. The priority items selected by the matrix during the analysis are items that will measurably increase the level of customer satisfaction. Hence, there is more emphasis on customers and increased awareness of their needs. Because of this focus, the process leads to customer understanding and customer satisfaction growth.

Green QFD

Environmental concerns have been introduced to new product developments especially since the 1990s. The term commonly referred to is eco-design or environmental design. Environmentally friendly design can be defined as product development that involves environmental concerns, taking into account environmental requirements that allow the reduction of environmental impacts in the product life cycle (Bakker, 1995). To improve the environmental aspects of the product, a number of practices are considered as simple methods, tools and guides for more complex techniques, such as life cycle management (Bovea and Wang, 2007). Among the eco-friendly design practices, some of them conform to the methods and tools already available in the product development knowledge body. One of the methods and tools that appear in the literature is QFD (construct quality functions). There have been many publications in the 'QFD environment' over the last ten years when compared to other methods and tools. One of the main advantages of using QFD in environmentally friendly designs is the ability to review environmental requirements while developing new products by translating these requirements into design specifications (Masui et al., 2001). Despite the merits of ecological design methods, some authors argue that new products are not always better in the environment (Ritzen and Lindah, 2001), and ecological practices do not always apply to product development (Knight and Jenkins, 2009). In this sense, this paper attempts to analyze a number of publications that suggest an ecological design method based on QFD. To do this, a systematic literature review was created. Twelve search ranges related to the terms 'QFD and eco-design', 'environmental design' and others were used to search 7 databases. As a result, 17 QFD-based methods published between 1993 and 2009 were identified.

\section{METHOD}

From each independent point of view, each alternative receives punctuation. To get the best conceptual design that integrates all these criteria together, the best conceptual design is selected.

1. Selection of two hospitals, hospital A [private] and hospital B [government].

2. Identification of medical waste

3. Preparation of questionnaires for surveys at Hospital A and Hospital B.

4. Data collection, in this study we selected a group consisting of 50 people (patients) and there were officers from hospitals A and B. And after conducting a survey of these people we arranged the quality of houses A and B.

5. Development of hospital quality A and B from customer requests and economical questionnaires, hospital transportation, hospital hygiene, doctor qualifications, attitude of hospital staff, hospital location, technological advances.

6. Development of greenhouses for hospital waste management from customer requests for work safety, harmless to the environment, environmentally friendly, departmental training, easy to handle, current waste management system, easy to treat waste from production to disposal. 


\begin{tabular}{|c|c|c|c|c|c|c|c|c|c|}
\hline & 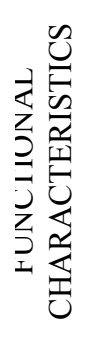 & 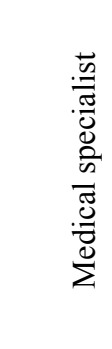 & 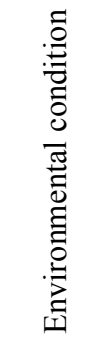 & 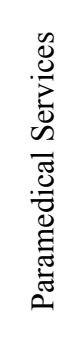 & 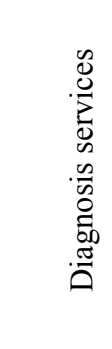 & 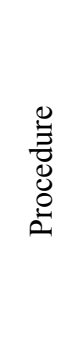 & 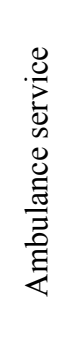 & $\begin{array}{l}\overline{\mathscr{O}} \\
\bar{\Xi} \\
\overline{0}\end{array}$ & \\
\hline \multicolumn{9}{|l|}{ CUSTOMER NEED } & \\
\hline Hospital transport & 2 & & & & & & $\mathrm{~s}$ & $\mathrm{~s}$ & \\
\hline Economical & 1 & $\mathrm{~s}$ & & & $\mathrm{~s}$ & $\mathrm{~s}$ & $\mathrm{~m}$ & & \\
\hline Hospital hygiene & 4 & & $\mathrm{~s}$ & $\mathrm{~m}$ & & & & & \\
\hline Doctor qualification & 5 & $\mathrm{~s}$ & & & $\mathrm{~s}$ & & & & \\
\hline Hospital staff attitude & 4 & & & $\mathrm{~m}$ & & & & & \\
\hline Hospital location & 2 & & $\mathrm{~s}$ & & & & $\mathrm{~m}$ & $\mathrm{~m}$ & \\
\hline Advanced technology & 5 & $\mathrm{~s}$ & $\mathrm{w}$ & & $\mathrm{s}$ & $\mathrm{m}$ & & & \\
\hline & 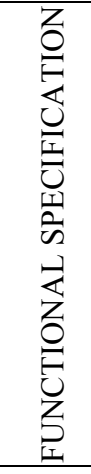 & 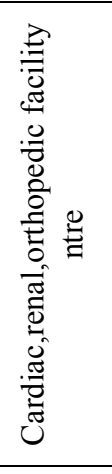 & 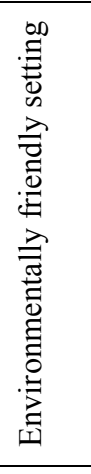 & 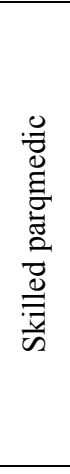 & 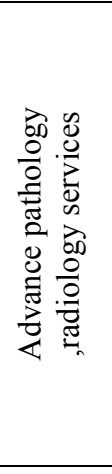 & 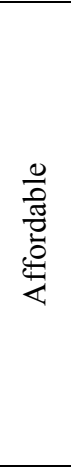 & $\begin{array}{l}\bar{\Xi} \\
\bar{d} \\
\bar{z} \\
\Xi \\
D \\
己\end{array}$ & 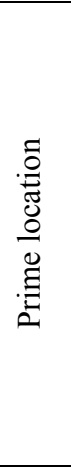 & \\
\hline ABSOLUTE IMPORTANCE & & 103 & 59 & 32 & 99 & 29 & 30 & 26 & $\mathrm{QI}=378$ \\
\hline $\begin{array}{r}\text { RELATIVE IMPORTANCE } \\
(\%)\end{array}$ & & 27,2 & 15,6 & 8,4 & 26 & 7,6 & 8 & 6,8 & \\
\hline $\begin{array}{rc}\mathrm{s}= & \text { strong }(9) \\
\mathrm{m}= & \text { medium }(4) \\
\mathrm{w}= & \text { weak }(1)\end{array}$ & & & & & & & & & \\
\hline
\end{tabular}

Figure 1 Green House Of Quality (HoS) for Private Hospital 


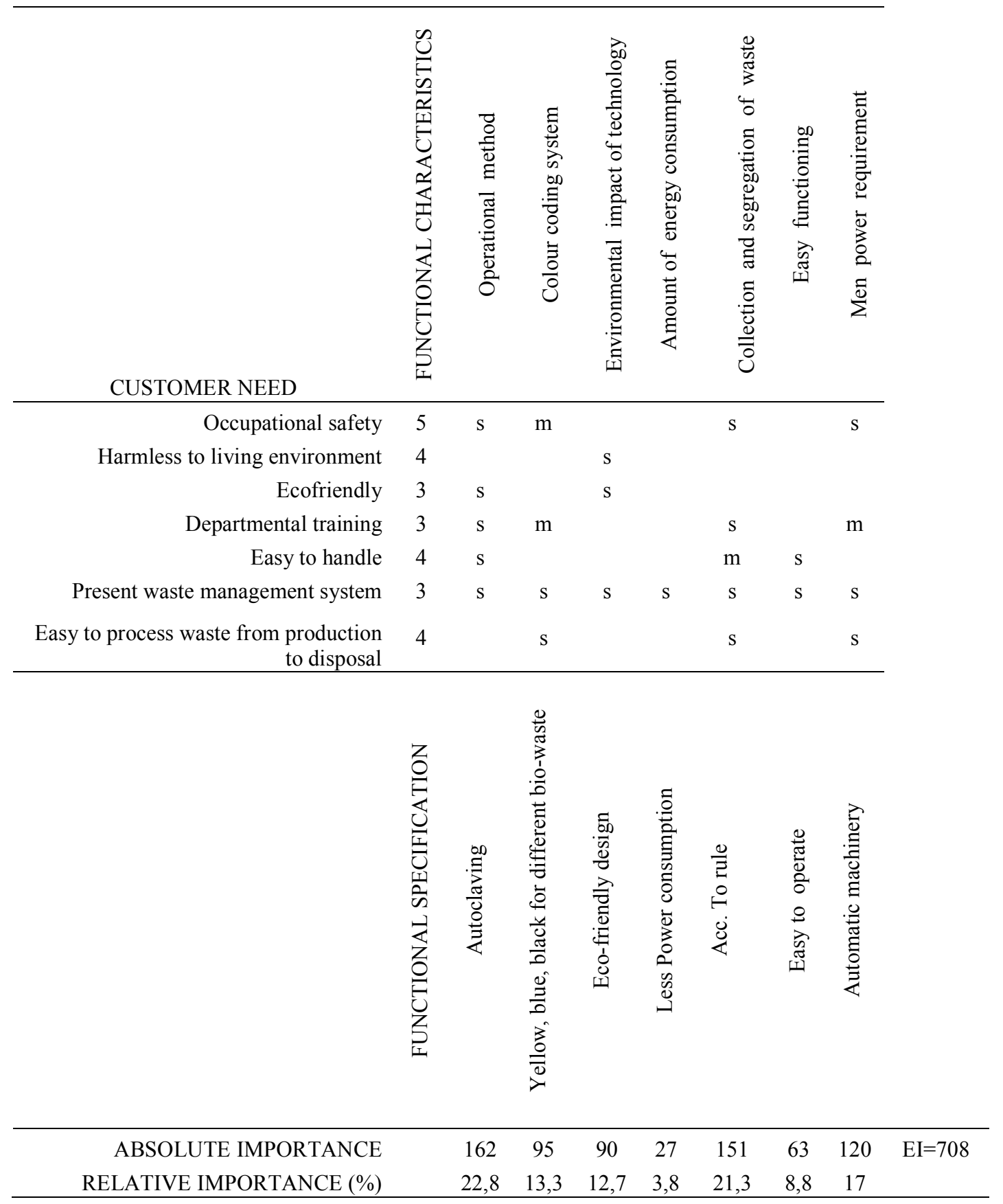

Figure 2 Green House Of Quality (HoS) for Public Hospital 
Table 1. Comparison Of House Of Quality Of Hospital A And Hospital B On The Basis Of Customer Need and Questionnaire Output:

\begin{tabular}{ccc}
\hline Customer Need & $\begin{array}{c}\text { Survey Output } \\
\text { (Hospital A) }\end{array}$ & $\begin{array}{c}\text { Survey Output } \\
\text { (Hospital B) }\end{array}$ \\
\hline Hospital transport & 2 & 1 \\
Economical & 1 & 2 \\
Hospital hygiene & 4 & 2 \\
Doctor qualification & 5 & 3 \\
Hospital staff attitude & 4 & 3 \\
Hospital location & 2 & 2 \\
Advanced technology & 5 & 2 \\
\hline
\end{tabular}

Table 2. Comparison Of Green House Of Quality For Hospital A And Hospital B On The Basis Of Customer Need and Questionnaire Survey:

\begin{tabular}{ccc}
\hline Customer Need & $\begin{array}{c}\text { Survey Output } \\
\text { (Hospital A) }\end{array}$ & $\begin{array}{c}\text { Survey } \\
\text { Output } \\
\text { (Hospital B) }\end{array}$ \\
\hline Occupational safety & 5 & 4 \\
Harmless to living environment & 4 & 2 \\
Eco-friendly & 3 & 2 \\
Departmental training & 3 & 3 \\
Easy to handle & 4 & 2 \\
Present waste management system & 3 & 2 \\
Easy to process & 4 & 1 \\
\hline
\end{tabular}

\section{DISCUSSION}

After the usage of the discused techniques, the result got from two type hospital in regards to their administrations in regard to customer need through QFD and hospital waste management through green QFD are summed up here The QFD results based on a questionnaire survey conducted in two hospitals A and B associated with customer need as discussed previously indicated that the quality index at hospital A is better than hospital B (as described in table 3 below).

Table 3. Comparison Between Environmental Index And Quality Index Of Hospital A And Hospital B

\begin{tabular}{ccc}
\multicolumn{3}{c}{ Of Hospital A And Hospital B } \\
\hline & ENVIRONMENTAL INDEX & QUALITY INDEX \\
\hline HOSPITAL A & 708 & 378 \\
HOSPITAL B & 463 & 348 \\
\hline
\end{tabular}

From the results of the survey and its implementation in QFD, it can be seen that the Quality Index and environmental index of hospital A are better than hospital B, therefore, improvement of services and waste management provided by Hospital B must be considered.

\section{CONCLUSIONS}

In studying various aspects of customer need and environmental factors in Hospital A and Hospital B through green QFD it was concluded that the quality and waste management system in Hospital A is better than Hospital B. Suggestions for improving service quality and waste management for hospital B are : 1) Recruitment specialist doctor and skilled paramedics. 2) Raise awareness of advanced and safe waste management systems. 


\section{REFERENCES}

[1] Sivaloganathan, S., and N.F.O. Evbuomwan. "Quality Function Deployment—The Technique: State of the Art and Future Directions." Concurrent Engineering 5, no. 2 (June 1997): 171-81.

[2] Alemam, Abdulbaset, and Simon Li. "Matrix-Based Quality Tools for Concept Generation in Eco-Design." Concurrent Engineering 24, no. 2 (June 2016): 113-28.

[3] Sharma, J. R., and A. M. Rawani. "Customer Driven Product Development Through Quality Function Development (QFD).” Asia Pacific Business Review 2, no. 1 (January 2006): 45-54.

[4] Ali, Mustafa, Wenping Wang, Nawaz Chaudhry, and Yong Geng. "Hospital Waste Management in Developing Countries: A Mini Review.” Waste Management \& Research 35, no. 6 (June 2017): 581-92.

[5] Lowe, Timothy J., Eugene Kroch, John Martin, and Richard Bankowitz. "Development of a Method to Measure and Compare Hospital Waste: The Premier Hospital Waste Index.” American Journal of Medical Quality 29, no. 1 (January 2014): 20-29.

[6] Yung, K. L., S. M. Ko, F. Y. Kwan, H. K. Tam, C. W. Lam, H. P. Ng, and K. S. Lau. "Application of Function Deployment Model in Decision Making for New Product Development." Concurrent Engineering 14, no. 3 (September 2006): 257-67.

[7] Lu, B., J. Zhang, D. Xue, and P. Gu. "Systematic Lifecycle Design for Sustainable Product Development." Concurrent Engineering 19, no. 4 (December 2011): 307-24.

[8] Li, Xiuzhen, Xinguo Ming, Wenyan Song, Siqi Qiu, Yuanju Qu, and Zhiwen Liu. “A Fuzzy Technique for Order Preference by Similarity to an Ideal Solution-Based Quality Function Deployment for Prioritizing Technical Attributes of New Products." Proceedings of the Institution of Mechanical EngineeHospital, Part B: Journal of Engineering Manufacture 230, no. 12 (December 2016): 2249-63

[9] Bencko, V., J. Kapek, and O. Vinš. "Hospital Waste Treatment and Disposal in the General UniveHospitality Hospital -Current Situation and Future Challenges.” Indoor and Built Environment 12, no. 1-2 (February 2003): 99104.

[10] Romli, Awanis, Rossitza Setchi, Paul Prickett, and Miguel P de la Pisa. "Eco-Design Case-Based Reasoning Tool: The Integration of Ecological Quality Function Deployment and Case-Based Reasoning Methods for Supporting Sustainable Product Design." Proceedings of the Institution of Mechanical EngineeHospital, Part B: Journal of Engineering Manufacture 232, no. 10 (August 2018): 1778-97.

[11] Eleyan, Derar, Issam A Al-Khatib, and Joy Garfield. "System Dynamics Model for Hospital Waste Characterization and Generation in Developing Countries.” Waste Management \& Research 31, no. 10 (October 2013): 986-95.

[12] Yang, Chaoxiang, Jianxin Cheng, and Xin Wang. "Hybrid Quality Function Deployment Method for Innovative New Product Design Based on the Theory of Inventive Problem Solving and Kansei Evaluation." Advances in Mechanical Engineering, (May 2019).

[13] Berkley, Blair J. "Designing Services With Function Analysis.” Hospitality Research Journal 20, no. 1 (February 1996): 73-100.

[14] Hanumantha Rao, P. "Hospital Waste Management System — a Case Study of a South Indian City." Waste Management \& Research 27, no. 4 (June 2009): 313-21.

[15] Iranmanesh, Seyed H, Hamid Rastegar, and Mohammad H Mokhtarani. "An Intelligent Fuzzy Logic-Based System to Support Quality Function Deployment Analysis.” Concurrent Engineering 22, no. 2 (June 2014): $106-22$.

[16] Cheaitou, Ali, Mickael Gardoni, and Sadeque Hamdan. "A Decision-Making Framework for Environmentally Sustainable Product Design.” Concurrent Engineering 27, no. 4 (December 2019): 295-304.

[17] Liberti, Lorenzo, Angelo TuHospitali, Nicola Costantino, Lorento Ferrara, and Gaetano Nuzzo. "Optimization of Infectious Hospital Waste Management in Italy: Part I-Wastes Production and Characterization Study." Waste Management \& Research 12, no. 5 (September 1994): 373-85

[18] Liang, Gin-Shuh, Ji-Feng Ding, and Chiao-Ling Pan. “Applying Fuzzy Quality Function Deployment to Evaluate Solutions of the Service Quality for International Port Logistics Centres in Taiwan." Proceedings of the Institution of Mechanical EngineeHospital, Part M: Journal of Engineering for the Maritime Environment 226, no. 4 (November 2012): 387-96.

[19] Liu, Xiaoqing Frank, Kunio Noguchi, and Weihua Zhou. "Requirement Acquisition, Analysis, and Synthesis in Quality Function Deployment.” Concurrent Engineering 9, no. 1 (March 2001): 24-36.

[20] Hanumantha Rao, P. "Report: Hospital Waste Management - Awareness and Practices: A Study of Three States in India." Waste Management \& Research 26, no. 3 (June 2008): 297-303.

[21]Lin, Ming-Chyuan, Chen-Cheng Wang, and Tzu-Chang Chen. "A Strategy for Managing Customer-Oriented Product Design.” Concurrent Engineering 14, no. 3 (September 2006): 231-44. 
[22] Mc Lennan, Anne, and Wendy Yolisa Ngoma. "Quality Governance for Sustainable Development?" Progress in Development Studies 4, no. 4 (October 2004): 279-93.

[23] Relvas, Carlos, and António Ramos. "New Methodology for Product Development Process Using Structured Tools." Proceedings of the Institution of Mechanical EngineeHospital, Part B: Journal of Engineering Manufacture 235, no. 3 (February 2021): 378-93.

[24] Townend, William K., and Christopher R Cheeseman. "Guidelines for the Evaluation and Assessment of the Sustainable Use of Resources and of Wastes Management at Healthcare Facilities." Waste Management \& Research 23, no. 5 (October 2005): 398-408.

[25] Pinto, Maria. "Data Representation FactoHospital and Dimensions from the Quality Function Deployment (QFD) PeHospitalpective.” Journal of Information Science 32, no. 2 (April 2006): 116-30. 